zeszyt 150, 2017, 29-40

doi: 10.4467/20833113PG.17.015.7319

Instytut Geografii i Gospodarki Przestrzennej UJ

Wydawnictwo Uniwersytetu Jagiellońskiego

\title{
MOŻLIWOŚCI WYKORZYSTANIA DANYCH Z LOTNICZEGO SKANOWANIA LASEROWEGO DO MODELOWANIA RZEŹBY DNA PROJEKTOWANEGO ZBIORNIKA WODNEGO PIETRASZKI (KIELCE)
}

\author{
Tadeusz Ciupa, Roman Suligowski, Grwegors Watek
}

\section{Possibilities of airborne laser scanning data use for model- ling of the designed Pietraszki water reservoir bottom relief (Kielce)}

\begin{abstract}
The paper presents the possibilities of the airborne laser scanning (ALS) data use in the morphological analysis of the bottom of the designed Pietraszki multi-purpose water reservoir, which is located in the mouth section of the Sufraganiec river $\left(5^{\text {th }}\right.$ rank $)$ in Kielce. The source material consisted of $0.5 \mathrm{~m}$ resolution digital terrain model created by the MGGP Aero company on the base of ALS point cloud obtained in 2011. The analysis was performed in SAGA GIS software and included modelling of the Sufraaniec valley bottom, where the reservoir's coastline was outlined, and a calculation of the reservoir's geometrical and morphological parameters. A practical effect of the analysis was the estimation of the ground masses volume that need to be moved in the investment area and also the designation of recreational zones along the reservoir's coastline. The performed analysis demonstrates the legitimacy of ALS digital terrain model use in detailed modelling of the planned reservoir bottom and also in outlining its coastline reach at the designed water levels.
\end{abstract}

Keywords: LiDAR, digital terrain model, water reservoir, bottom topography

Zarys treści: W pracy zaprezentowano możliwości wykorzystania danych z lotniczego skanowania laserowego (ALS) do analizy morfologicznej czaszy projektowanego, wielozadaniowego 
zbiornika wodnego Pietraszki, zlokalizowanego u ujścia rzeki Sufraganiec (V rząd) w Kielcach. Materiał źródłowy stanowił numeryczny model terenu o strukturze GRID i wymiarze oczka siatki $0,5 \mathrm{~m}$, opracowany przez firmę MGGP Aero na podstawie chmury punktów z nalotu wykonanego w 2011 r. Procedurę analityczną przeprowadzono z użyciem oprogramowania SAGA GIS, w którym dokonano modelowania dna doliny Sufragańca wyznaczając linię brzegową planowanego zbiornika wodnego, a następnie jego parametry geometryczne i morfologiczne. Efektem praktycznym tych prac, analiz i symulacji było określenie kubatury mas ziemnych przeznaczonych do przemieszczenia w obrębie projektowanego zbiornika $\mathrm{w}$ trakcie realizacji inwestycji, a także wydzielenie stref rekreacyjnego zagospodarowania jego brzegów. Wykazano zasadność zastosowania numerycznego modelu terenu, opracowanego na podstawie danych ALS, do szczegółowego modelowania linii brzegowej oraz rzeźby dna projektowanego zbiornika wodnego przy ustalonych dwóch poziomach piętrzenia.

Stowa kluczowe: LiDAR, numeryczny model terenu, zbiornik wodny, topografia dna

\section{Wstęp}

W sąsiedztwie dużych miast, gdzie nie występują naturalne akweny, istnieje potrzeba budowy zbiorników wodnych pełniących funkcję rekreacyjną. Na etapie projektowania tych obiektów, oprócz określenia zasobów i stanu czystości wód w zlewni zbiornikowej, istotne jest wyznaczenie przebiegu linii brzegowej, rozpoznanie rzeźby dna oraz parametrów geometrycznych zbiornika. W tym celu dotychczas wykorzystywano głównie szczegółowe mapy topograficzne, jak również mapy zasadnicze, wyniki pomiarów geodezyjnych, materiały fotogrametryczne w formie obrazów satelitarnych i zdjęć lotniczych (ortofotomap). W ostatnich latach, w związku z rozwojem technik teledetekcyjnych, pojawiło się nowe źródło wysokorozdzielczych danych, pochodzących z lotniczego skanowania laserowego (ang. ALS - Airborne Laser Scanning) (Jędrychowski 2007; Affek 2014). Dane te mogą być wykorzystane do opracowania modelu wysokościowego umożliwiającego wykonanie bardzo dokładnych charakterystyk morfometrycznych zbiornika, które są niezbędne do określenia: jego pojemności, przestrzennego rozkładu głębokości, wizualizacji rzeźby dna, opracowania profili morfologicznych, a także zaplanowania niezbędnych prac ziemnych w obrębie jego czaszy i w strefie brzegowej. W literaturze przedmiotu istnieje wiele przykładów zastosowania skanowania laserowego w badaniach geomorfologicznych (Webster i in. 2006; Kasprzak, Traczyk 2010; Höfle, Rutzinger 2011; Bremer, Sass 2012; Bernardini i in. 2013; Migoń i in. 2013; Wójcik i in. 2013; Sailer i in. 2014), w tym w dolinach rzecznych (Borkowski i in. 2006; Gołuch i in. 2009; Kasprzak, Traczyk, 2011; Florek, Tylman 2013; Kowalski 2013; Wierzbicki in. 2013; Brach, Chormański 2014). W ramach projektu ISOK dane pozyskane z lotniczego skaningu laserowego wykorzystuje się do opracowania numerycznych modeli terenu dolin rzecznych i hydrologicznych interpretacji, w tym zasięgu wód 
wezbraniowych oraz zagrożenia powodziowego (Kowalski 2013; Kurczyński, Bakuła 2013; Pawłuszek i in. 2014). Stosowano ja również do analiz rzeźby dna naturalnych akwenów, w tym w morskiej strefie brzegowej (Dudzińska-Nowak, Wężyk 2006). Technika ta dotychczas nie znalazła jednak większego zastosowania w projektowaniu sztucznych zbiorników wodnych w Polsce, z uwzględnieniem modelowania linii brzegowej i morfologii dna.

Celem pracy jest ukazanie możliwości wykorzystania danych z lotniczego skanowania laserowego do analizy morfologicznej czaszy projektowanego, wielozadaniowego zbiornika wodnego o nazwie Pietraszki (dolina Sufragańca w Kielcach).

\section{Materiały źródłowe}

W pracy wykorzystano numeryczny model terenu (NMT) opracowany na podstawie chmury punktów z lotniczego skanowania laserowego wykonanego 27 i 28 września 2011 r. przez firmę MGGP S.A. na zamówienie Urzędu Miasta Kielce. Podczas 4 nalotów, których średnia wysokość wynosiła 660 m, użyto śmigłowca Eurocopter 120 z systemem LiteMapper LMSQ680i. W efekcie uzyskano średnią gęstość 28 punktów na $1 \mathrm{~m}^{2}$, co oznacza znacznie większą dokładność reprezentacji powierzchni terenu niż w standardzie ISOK. Powstała chmura punktów w formacie LAS, zarchiwizowana w Układzie 2000 - strefa 7, oprócz współrzędnych XYZ otrzymała także atrybut klasyfikacji, zgodnie ze standardem ASPRS (m.in. grunt, roślinność: niska, średnia, wysoka). Numeryczny model terenu o strukturze GRID i wymiarze oczka siatki $0,5 \mathrm{~m}$ został przygotowany przez ww. firmę w programie TerraSolid z wykorzystaniem punktów sklasyfikowanych jako powierzchnia gruntu i algorytmu interpolacyjnego nieregularnej sieci trójkątów (ang. TIN - Triangular Irregular Network). Wymagało to dokładnego odfiltrowania innych punktów, reprezentujących obiekty nienależące do terenu (np. budynki, roślinność, szum). Dokładność wysokościowa tego modelu charakteryzuje się błędem średnim $\mathrm{m}_{\mathrm{z}}< \pm 0,15 \mathrm{~m}$, a sytuacyjna $\mathrm{m}_{\mathrm{p}}< \pm 0,5 \mathrm{~m}$. Wyliczenia pochodzą z raportu wykonawcy (MGGP Aero 2011), ale biorąc pod uwagę jakość danych (gęstość), są one niższe niż dokładność danych LiDAR, np. w ramach ISOK standard II, a wręcz zbliżone do dokładności w standardzie I. Na podobne do deklarowanych wielkości błędu wskazują ustalenia innych autorów. Na przykład badania Pawłuszek i in. (2015) przeprowadzone w dolinie Widawy w obrębie poletek testowych o różnym zagospodarowaniu wykazały, że na użytkach zbliżonych do tych, które znajdują się w dolinie rzeki Sufraganiec, dokładność wewnętrzna danych wyrażona odchyleniem standardowym mieściła się w przedziale 0,03-0,31 m i była nieco większa niż w miejscach pozbawionych pokrywy roślinnej w dniu nalotu - np. na gruntach ornych $(0,08-0,18 \mathrm{~m})$. Ocena dokładności wysokości 
z danych ALS z rzędnymi punktów referencyjnych prezentowanych na arkuszach mapy zasadniczej obejmującej obszar opracowania wskazuje, że średni błąd kwadratowy na podstawie analizy 1085 par punktów był zbliżony do ww. wartości zadeklarowanej przez wykonawcę.

\section{Metody badań}

Procedurę analityczną zmierzającą do realizacji celu pracy przeprowadzono z użyciem oprogramowania SAGA GIS (Conrad i in. 2015). Linię brzegową wyznaczono poprzez warstwicę bazową, uwzględniając dwa poziomy piętrzenia wody w planowanym zbiorniku - normalny (224,0 m n.p.m.) i maksymalny (224,4 m n.p.m.). Następnie, biorąc pod uwagę rzeźbę terenu dna doliny z istniejącymi tu rowami melioracyjnymi i naturalnymi zagłębieniami terenu, a także obecność miąższych gruntów organicznych, przeprowadzono modelowanie terenu polegające na usunięciu warstwy humusu oraz mikroniwelacji dna projektowanego zbiornika. W tym celu wykorzystano funkcje algebry mapy ('Tomlin 1990). W zasięgu gruntów organicznych obniżono wysokość NMT o ich średnią miąższość $(0,3 \mathrm{~m})$. Następnie przeprowadzono dwukrotnie procedurę przepróbkowania (ang. resampling) komórki NMT z rozmiaru 0,5 m do $5 \mathrm{~m}$, a następnie ponownie do $0,5 \mathrm{~m}$. Podczas modelowania dna zachowano istniejący przebieg koryta Sufragańca. W rezultacie przeprowadzonych operacji otrzymano model terenu dna zbiornika o wygładzonej powierzchni, który posłużył do dalszych interpretacji. Analizując zmiany wysokości względnych terenu, za pomocą narzędzia Grid Volume, obliczono kubaturę mas ziemnych przeznaczonych do przemieszczenia. Profile dna projektowanego zbiornika wyznaczono z użyciem narzędzia Profiles from Lines, analizy batymetryczne natomiast - funkcjami Lake Flood oraz Hypsometry. Przestrzenny rozkład spadków dna projektowanego zbiornika wygenerowano metodą Zevenbergena i Thorne'a (1987). Aspekty metodyczne obliczeń hydrologicznych szczegółowo omówiono w publikacji Ciupy i Suligowskiego (2015).

\section{Teren badań}

Projektowany zbiornik wodny Pietraszki jest jednym z elementów składowych programu małej retencji w województwie świętokrzyskim (Suligowski i in. 2009). Będzie on zlokalizowany w granicach administracyjnych Kielc, w dolnej części zlewni rzeki Sufraganiec, który jest lewobrzeżnym dopływem Bobrzy w dorzeczu Nidy (ryc. 1). Rzeka ta (V rzędu), o długości 16,13 km i średnim spadku 8,3\%o, odwadnia zlewnię leśno-rolniczą z rosnącym w dół biegu rzeki udziałem terenów zurbanizowanych (Ciupa i in. 2015). 
Powierzchnia całej zlewni Sufragańca wynosi $61,98 \mathrm{~km}^{2}$, a zlewni po projektowaną zaporę-61,43 $\mathrm{km}^{2}$. Zapora czołowa (dwuskrzydłowa) zlokalizowana będzie w strefie przełomowej między Górą Marmurek a Machnowicą, w km 0+450 m biegu rzeki. Jej długość wynosić będzie 1162 m, a rzędna korony 244,8 m n.p.m.

W starszym podłożu projektowanego zbiornika Pietraszki występują utwory triasu dolnego i permu górnego (piaskowce i mułowce z przewarstwieniami iłowców, zlepieńce), a na południowym skraju projektowanej inwestycji - skrasowiałe wapienie dewonu środkowego (Filonowicz 1973), o współczynnikach filtracji od $1 \cdot 10^{-4} \mathrm{~m} \cdot \mathrm{s}^{-1} \mathrm{do}$ $1 \cdot 10^{-5} \mathrm{~m} \cdot \mathrm{s}^{-1}$. W ich obrębie wydzielono główny zbiornik wód podziemnych GZWP 417 - Kielce, intensywnie eksploatowany na potrzeby 200-tysięcznego miasta (Prażak 2012). Analiza uwarunkowań hydrogeologicznych wskazuje na możliwość infiltracji wód z akwenu i ich napływu do studzien ujęć komunalnych. Dno doliny Sufragańca na analizowanym odcinku wyścielają piaski rzeczne i wodnolodowcowe (średni współczynnik filtracji - ok. $1 \cdot 10^{-5} \mathrm{~m} \cdot \mathrm{s}^{-1}$ ) związane ze zlodowaceniem środkowopolskim, terasy zaś nadzalewowe budują piaski rzeczne ze żwirami z okresu zlodowacenia północnopolskiego. Pod nimi zalegają piaski i mułki zastoiskowe (współczynniki filtracji - poniżej $1 \cdot 10^{-6} \mathrm{~m} \cdot \mathrm{s}^{-1}$ ) wypełniające głęboko (do $40 \mathrm{~m}$ ) wciętą w starsze podłoże dolinę kopalną, udokumentowaną badaniami geofizycznymi. W obrębie czaszy proponowanego zbiornika wodnego występują także osady organiczne o miąższości do kilkudziesięciu centymetrów, gdzie wyróżnia się gleby murszowe i torfowo-murszowe. Koryto Sufragańca na tym odcinku jest sztucznie ukształtowane, a w szerokim rozszerzeniu dna doliny (do 1,2 km) powyżej przełomu występują liczne starorzecza.

Wartość użytkowa tego terenu pod względem rolniczym jest mała, ranga walorów przyrodniczych natomiast - dość duża, o czym świadczy objęcie fragmentu tego obszaru różnymi formami ochrony (Chęcińsko-Kielecki Park Krajobrazowy, Kielecki Obszar Chronionego Krajobrazu i SOO Dolina Bobrzy).

Zbiornik wodny będzie zasilany wodami Sufragańca, który płynie na znacznej długości wzdłuż północno-zachodnich obrzeży Kielc. Otrzymuje on kilka bezimiennych cieków oraz dwa lewobrzeżne dopływy: Sufragańczyk i Dopływ z Czarnowa. Ten ostatni jest odbiornikiem wody z 4 zlewni kanałowych - funkcjonujących w systemie kanalizacji burzowej miasta. Szczególnego znaczenia w zasilaniu rzeki głównej nabierają one latem, gdy siecią kanalizacji następuje przyspieszony odpływ wód opadowych, oraz wiosną po roztopach. Reżim przepływu Sufragańca można okreŚlić jako złożony, z dwoma maksimami w ciągu roku (wiosenne: marzec-kwiecień, i letnie: czerwiec). Podczas wezbrań letnich występują wysokie odpływy, będące hydrologicznym efektem dużego wzrostu udziału terenów uszczelnionych w zachodnich dzielnicach Kielc. Średnia roczna wartość odpływu jednostkowego ze zlewni planowanego zbiornika wodnego wynosi $8,81 \cdot \mathrm{s}^{-1} \cdot \mathrm{km}^{-2}$, współczynnik odpływu -39\%, a objętość odpływu $-17,2 \mathrm{mln} \mathrm{m}^{3}$. Średni roczny przepływ Sufragańca w przekroju 


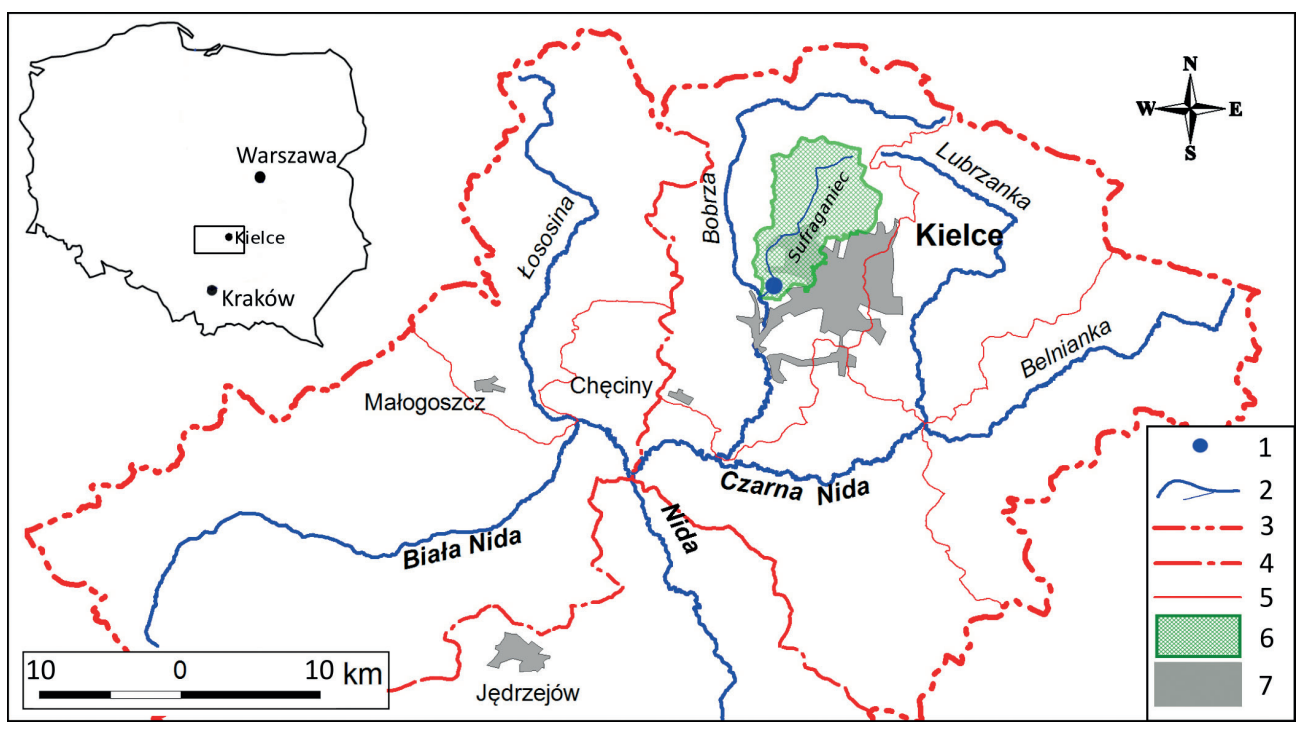

Ryc. 1. Położenie projektowanego zbiornika wodnego Pietraszki

Fig. 1. Location of the designed Pietraszki water reservoir

\section{Objaśnienia:}

1 - lokalizacja projektowanego zbiornika; 2 - rzeki; 3 - dział wodny II rzędu; 4 - dział wodny III rzędu; 5 - dział wodny IV rzędu i wyższych; 6 - zlewnia Sufragańca; 7 - zabudowa miejska.

Explanations:

1 - location of the designed reservoir; 2 - rivers; $3-2^{\text {nd }}$ order water divide; $4-3$ rd order water divide; $5-4^{\text {th }}$ and higher order water divides; 6 - Sufraganiec catchment; 7 - urban built-up area. 


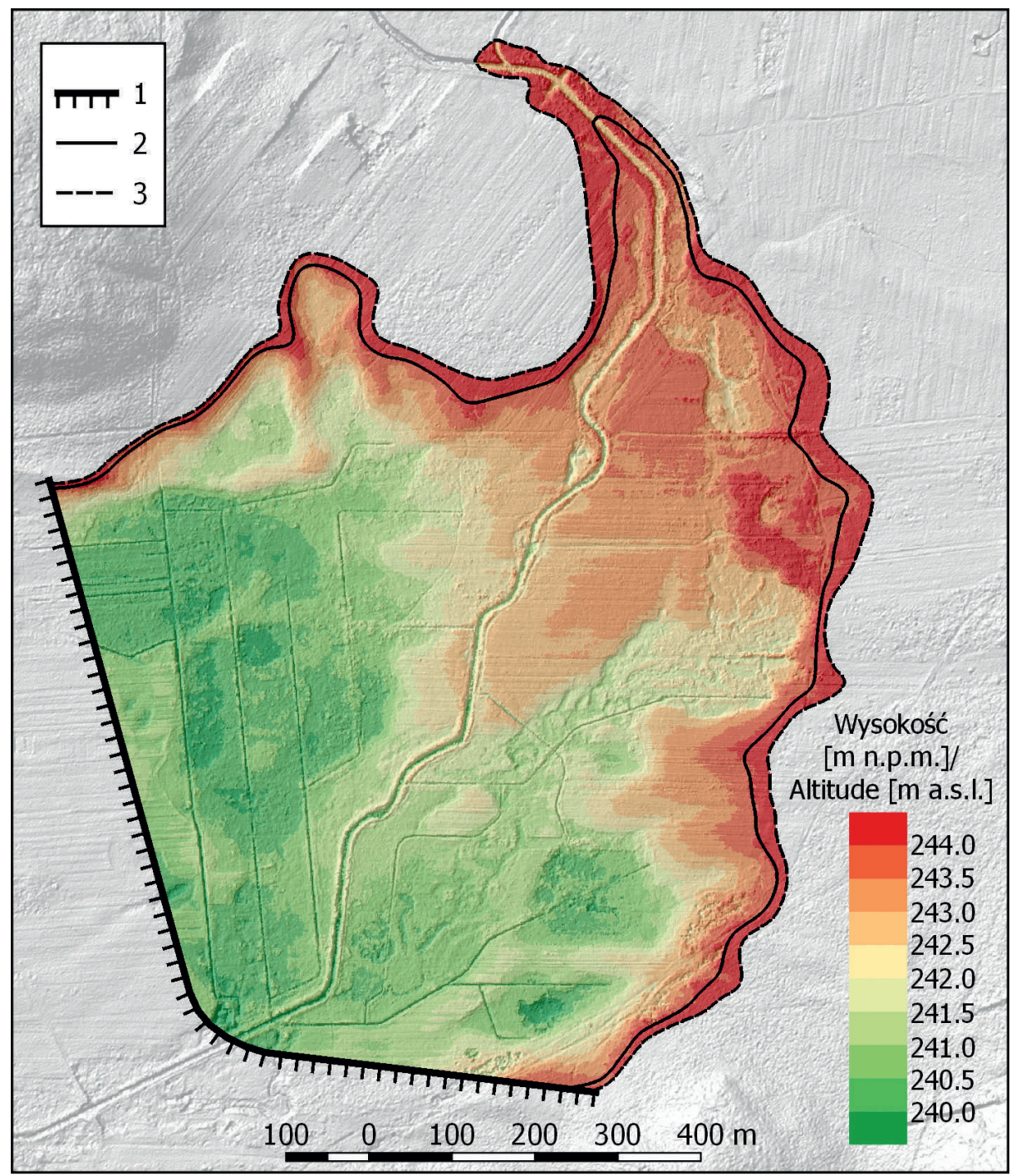

Ryc. 2. Numeryczny model rzeźby terenu dna zbiornika Pietraszki na podstawie lotniczego skanowania laserowego

Fig. 2. Digital terrain model of the bottom of the Pietraszki reservoir based on airborne laser scanning data

\section{Objaśnienia:}

1 - zapora zbiornika wodnego; linia brzegowa zbiornika przy: 2 - normalnym poziomie piętrzenia (NPP); 3 - maksymalnym poziomie piętrzenia (MPP).

\section{Explanations:}

1 - dam; coastline: 2 - at normal water level (NPP); 3 - at maximum water level (MPP).

Źródto: opracowanie własne na podstawie danych z Miejskiego Systemu Informacji Præestrzennej w Kielcach. Source: author's own work based on data from the Urban Geographical Information System in Kielce. 


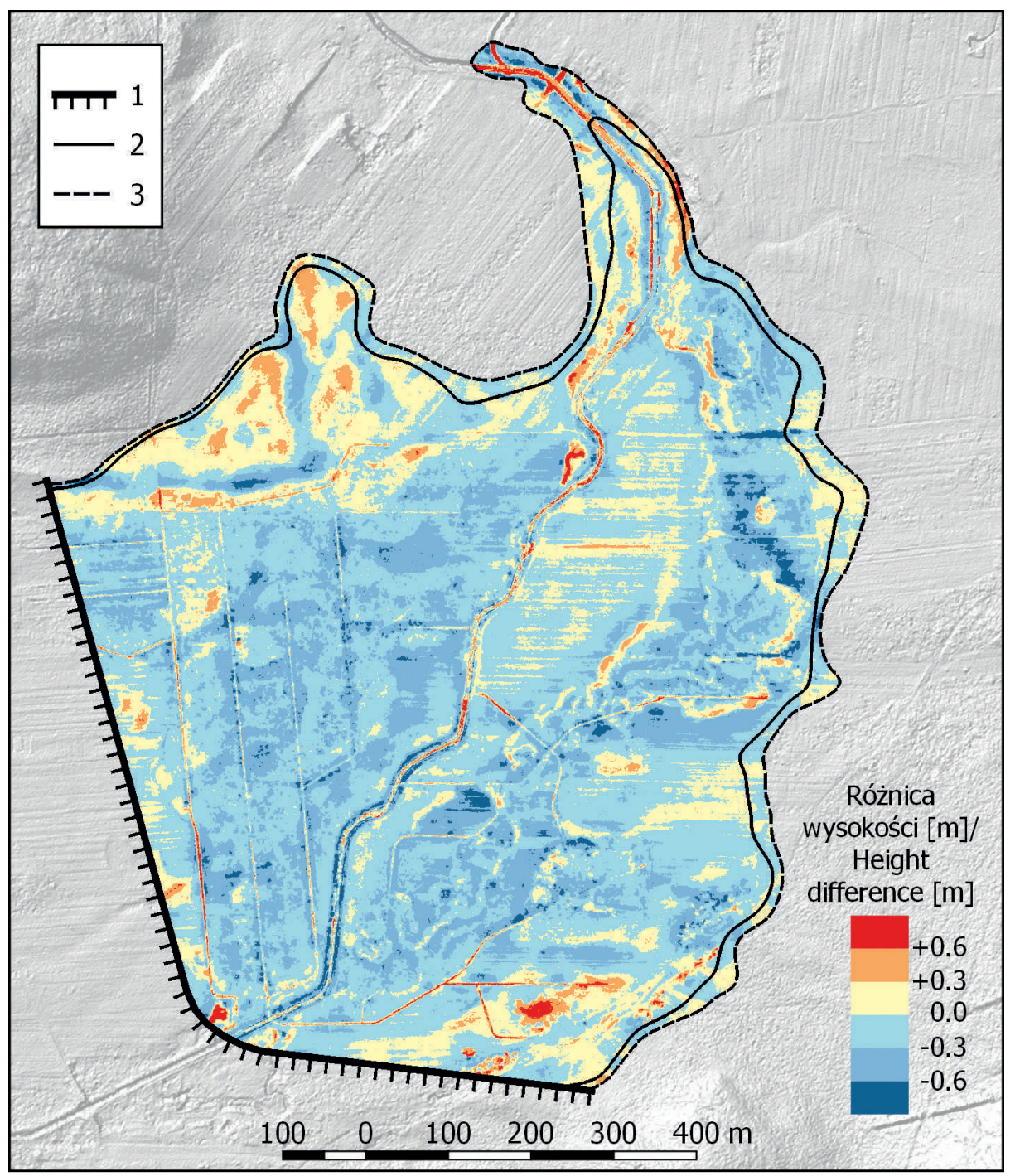

Ryc. 3. Zmiany wysokości względnych terenu (m) po zdjęciu warstwy humusu oraz wykonaniu prac mikroniwelacyjnych. Objaśnienia jak na ryc. 2

Fig. 3. Relative height changes $(\mathrm{m})$ after removal of humus layer and ground micro-levelling. Explanations as in Fig. 2

Źródto: opracowanie własne na podstawie danych z Miejskiego Systemu Informacji Przestrzennej w Kielcach. Source: author's own work based on data from the Urban Geographical Information System in Kielce. 


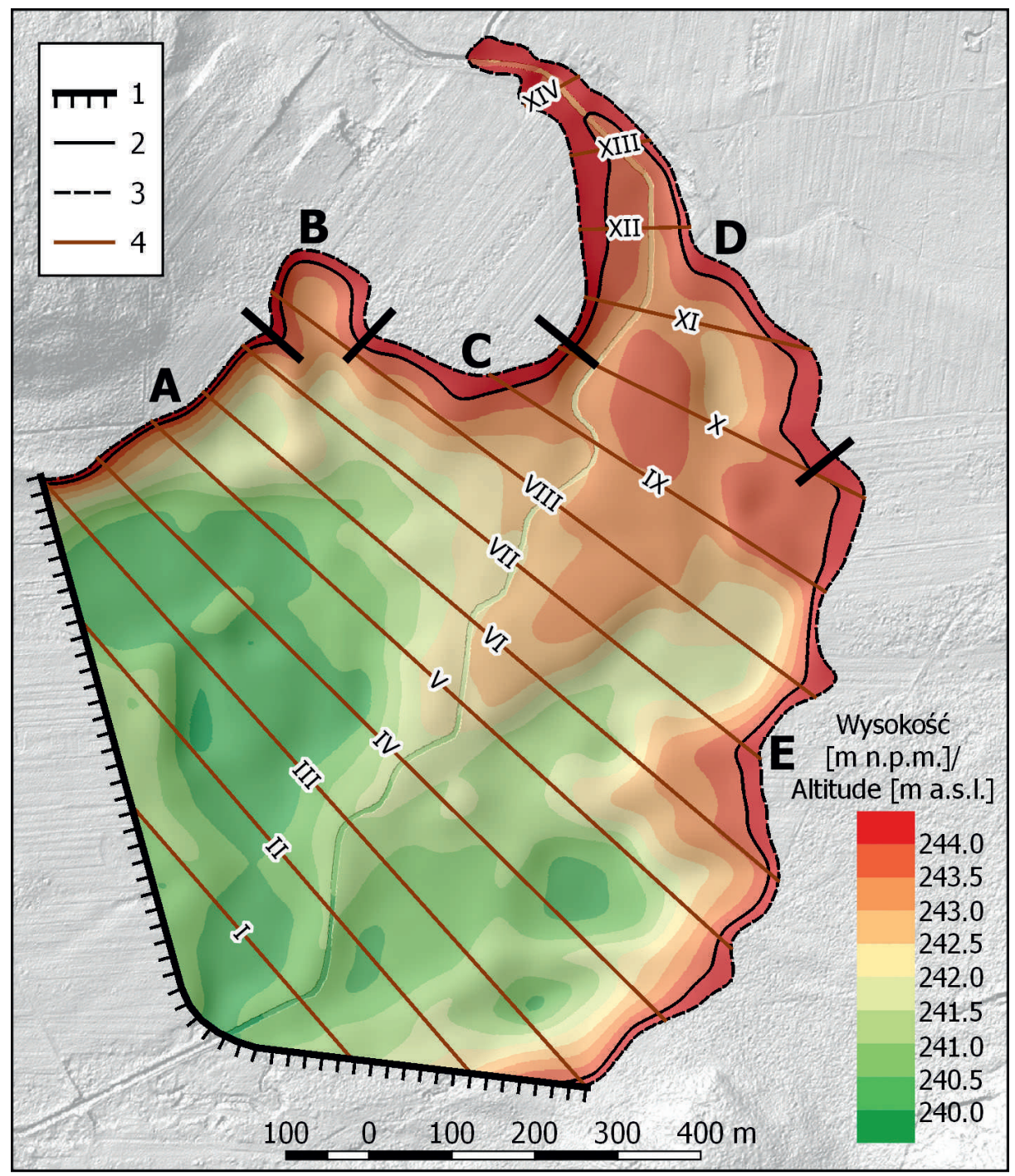

Ryc. 4. Rzeźba terenu dna zbiornika Pietraszki po przeprowadzeniu modelowania Fig. 4. Relief of the bottom of the Pietraszki reservoir after its micro-levelling

\section{Objaśnienia:}

1 - zapora zbiornika wodnego; linia brzegowa zbiornika przy: 2 - normalnym poziomie piętrzenia (NPP); 3 - maksymalnym poziomie piętrzenia (MPP); 4 - profile wraz z numeracją.

\section{Explanations:}

1 - dam; coastline: 2 - at normal water level (NPP); 3 - at maximum water level (MPP); 4 - numbered bathymetric profiles.

Źródto: opracowanie własne na podstawie danych z Miejskiego Systemu Informacji Præestrzennej w Kielcach. Source: author's own work based on data from the Urban Geographical Information System in Kielce. 
wysokości zmienią się w przedziale od -0,6m (pogłębienie) do +0,6m (nadsypanie), a lokalnie mogą osiągnąć jeszcze większe wartości.

Analiza wykazała, że objętość warstwy humusu wymagającego przemieszczenia poza zasięg zbiornika wyniesie 105 tys. $\mathrm{m}^{3}$. Materiał ten można wykorzystać częściowo do umocnienia i obsiania trawą odpowietrznej skarpy zapory czołowej. Opracowany bilans mas ziemnych związanych z planowanymi pracami mikroniwelacyjnymi wskazuje, że przemieszczenia będzie wymagało ok. 30 tys. $\mathrm{m}^{3}$ gruntu, ale jedynie w obrębie czaszy zbiornika - bez konieczności wywozu poza jego zasięg. Generalnie, symulowana rzeźba dna zbiornika będzie zbliżona do obrazu pierwotnego (ryc. 4). Profile rzeźby terenu ukazują dość duże zróżnicowanie rzędnych dna zbiornika nawet po dokonaniu prac ziemnych (ryc. 5). Widoczne jest na nich nienaturalnie wysoko położone koryto Sufragańca (np. profil III i V) w stosunku do dna doliny. Jest to morfologiczny efekt regulacji i przesunięcia rzeki, a także z usypania prowizorycznych „wałów przykorytowych”, mających zabezpieczać ówczesne łąki kośne przed zalaniem.

Mapa spadków dna projektowanego zbiornika wodnego wskazuje, że w środkowej jego części będą dominowały nachylenia w przedziale $0-1^{\circ}$, w strefie brzegowej wzrosną do $2-3^{\circ}$, a tylko w NW części będą nieco wyższe ( $4^{\circ}$ ) (ryc. 6).

Przeprowadzona analiza przebiegu linii i strefy brzegowej zbiornika wykazała, że można wyróżnić tu kilka różnych odcinków o odmiennej morfologii i szeroko-
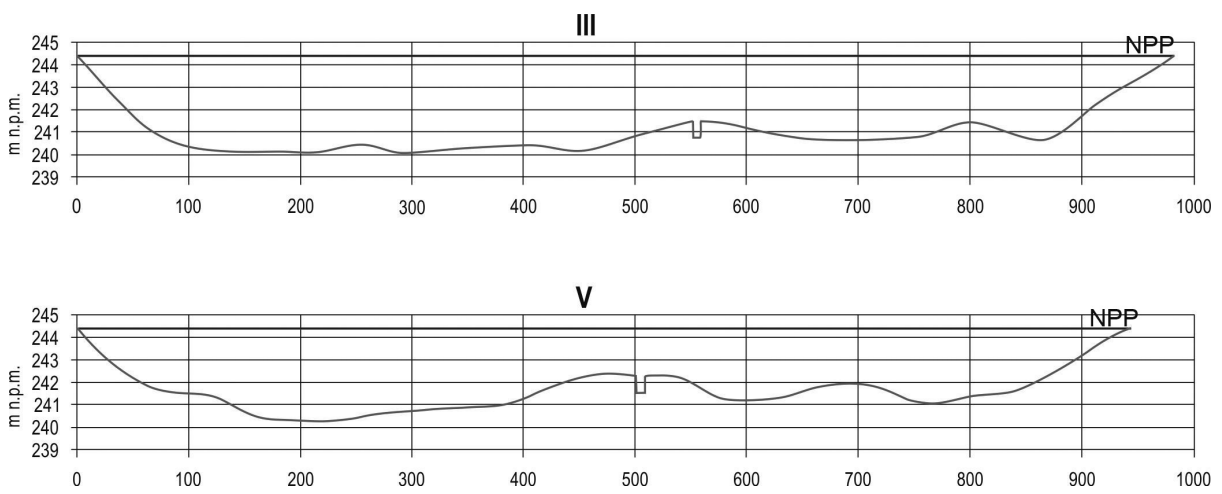

Ryc. 5. Wybrane profile rzeźby dna zbiornika Pietraszki w dolinie rzeki Sufraganiec i rzędna lustra wody przy normalnym poziomie piętrzenia (NPP)

Fig. 5. Chosen bathymetric profiles of the bottom of the Pietraszki water reservoir in the Sufraganiec river valley, normal water level (NPP)

Źródto: opracowanie własne na podstawie danych z Miejskiego Systemu Informacji Præestræennej w Kielcach. Source: author's own work based on data from the Urban Geographical Information System in Kielce. 
Ści strefy brzegowej (nawodnej i podwodnej), ekspozycji i wynikającego z tego nasłonecznienia. Utworzy się tu kilka zatok i niewielkich cypli, podkreślając w ten sposób walory widokowe krajobrazu. Od północno-zachodniego przyczółka zapory, w kierunku NE na odcinku ok. 350 m linia brzegowa będzie przecinała dolną część stoku Góry Machnowica (odcinek A, ryc. 4). Na całym tym odcinku w odległości $10 \mathrm{~m}$ od brzegu zbiornik osiągnie głębokość $0,6 \mathrm{~m}$, a w odległości $20 \mathrm{~m}$ - już 1,6 m. Te naturalne predyspozycje strefy brzegowej mogłyby być wykorzystane do lokalizacji tu przystani dla sprzętu pływającego. Kolejny odcinek (B) o długości ok. $250 \mathrm{~m}$ będzie obejmował największą zatokę w obrębie planowanego zbiornika - o szerokości ok. 80 m. Zatoka ta może oddzielać dwie strefy zagospodarowania rekreacyjnego. Następny, ok. 300-metrowy odcinek (C), będzie charakteryzował się znacznie większym rozwinięciem linii brzegowej, szerszą strefą nawodną i podwodną, ekspozycją w kierunku od SE do SW, co będzie sprzyjało tu zorganizowaniu miejsc do plażowania i korzystania z kąpieli. Czwarty odcinek linii brzegowej (D) o długości ok. $750 \mathrm{~m}$ będzie położony w strefie zasilania zbiornika wodami Sufragańca. Jego cechą będzie niewielka szerokość i głębokość, co może sprzyjać procesom akumulacji i w efekcie powstawaniu delty i płycizn. Pojawi się tu roślinność wodolubna i gatunki fauny związane z wodami stojącymi. Obszar ten powinien być wyłączony z użytkowania rekreacyjnego. Ostatni odcinek linii brzegowej (E), o długości 950 m, będzie przebiegał we wschodniej części zbiornika, ze zmiennymi głębokościami w strefie podwodnej (ryc. 4). Na znacznej długości położony on będzie wzdłuż granicy lasu. Sprzyja to wybudowaniu tu infrastruktury komunikacyjnej (ścieżek rowerowych, ciąów spacerowych) i towarzyszącej turystyce (stanowiska wędkarskie, park linowy itp.).

W obrębie planowanego zbiornika wystąpi dość duże zróżnicowanie głębokości. Największa głębokość przy NPP, niezależnie od wariantu lokalizacji zapory, znajdzie się przy zaporze - w północno-zachodniej części jego czaszy, osiągając 4,2 m. W tej strefie akwenu duży udział mają głębokości powyżej 3,5 m (15\% powierzchni przy NPP i $20 \%$ przy MPP). Ta część zbiornika może być przeznaczona do uprawiania aktywnych form turystyki wodnej (kajakarstwo, żeglarstwo). Górna część planowanego zbiornika charakteryzuje się małymi głębokościami, nieprzekraczającymi 1,0 m (ryc. 7). Na etapie projektu technicznego można tu zaplanować utworzenie wyspy.

Dane z numerycznego modelu terenu, opracowane po dokonaniu mikroniwelacji w obrębie dna projektowanego zbiornika, wykorzystano do wykonania krzywych: batygraficznej (zwaną również krzywą powierzchni zalewu) oraz pojemności. W celu uzyskania bardzo dokładnego ich obrazu, zastosowano całkowanie powierzchni terenu w pięciocentymetrowych przedziałach wysokości, uwzględniając jednocześnie dwa poziomy piętrzenia. Pozwoliło to wyznaczyć podstawowe parametry zbiornika (powierzchnię i objętość) przy dwóch założonych, jak i dowolnych, rzędnych piętrzenia (Ciupa, Suligowski 2015), umożliwiające prowadzenie właściwej 


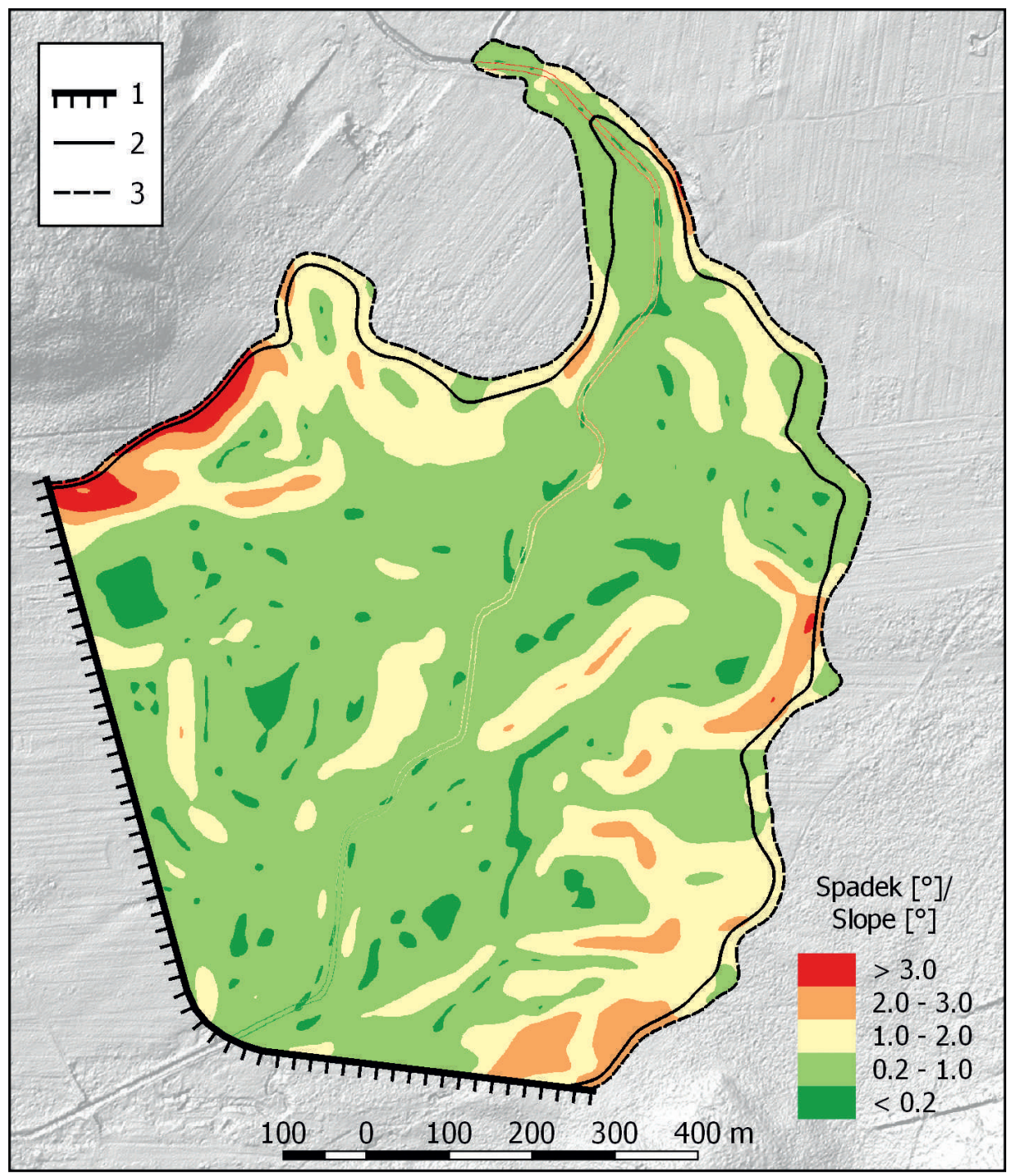

Ryc. 6. Spadki dna projektowanego zbiornika „Pietraszki”, po dokonaniu niwelacji mikroform. Objaśnienia jak na Rys. 2

Fig. 6. Terrain slope of the bottom of the Pietraszki water reservoir after humus removal and ground micro-levelling. Explanations as in Fig. 2

Źródto: opracowanie własne na podstawie danych z Miejskiego Systemu Informacji Przestrzennej w Kielcach. Source: author's own work based on data from the Urban Geographical Information System in Kielce. 


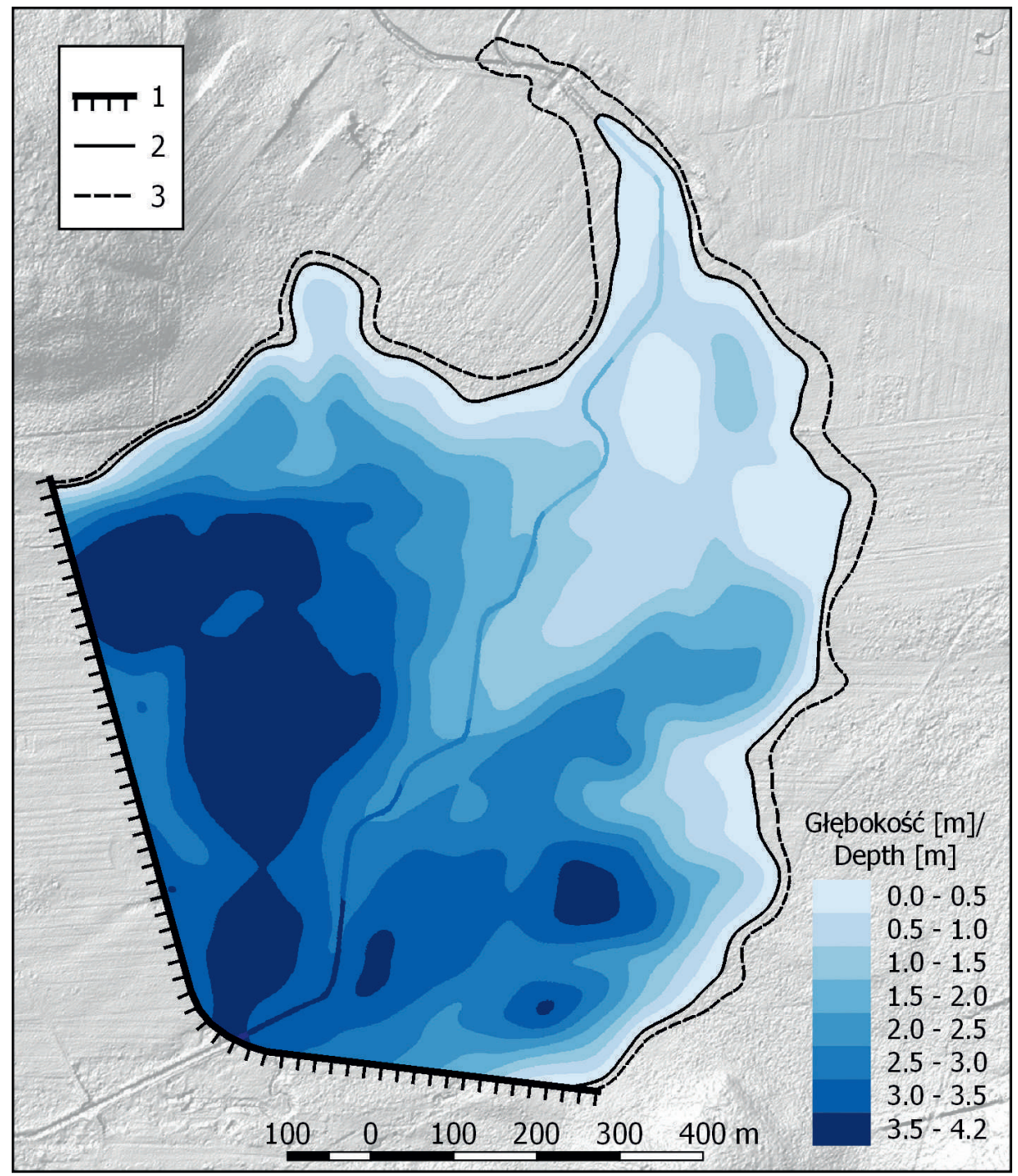

Ryc. 7. Przestrzenny rozkład głębokości zbiornika wodnego Pietraszki przy NPP. Objaśnienia jak na ryc. 2

Fig. 7. Bathymetric map of the Pietraszki water reservoir at normal water level (NPP). Explanations as in Fig. 2

Źródto: Ciupa, Suligowski (2015) ze zmianami.

Source: Ciupa and Suligowski (2015) with changes. 
gospodarki wodnej na zbiorniku. Powierzchnia lustra wody przy MPP wynosi 74,37 ha, a przy NPP - 68,92 ha, co pozwala na zgromadzenie w zbiorniku odpowiednio: $1668300 \mathrm{~m}^{3}$ oraz $1373700 \mathrm{~m}^{3}$ wody. Wyniki tych prac stały się punktem wyjścia wykonania niezbędnych obliczeń hydrologicznych wykorzystywanych w analizach projektowych, a w szczególności: wielkości rezerwy powodziowej (różnica pojemności między MPP i NPP oraz czasu napełniania zbiornika. Rezerwa powodziowa zbiornika osiągnie 294,6 tys. $\mathrm{m}^{3}$, co oznacza, że zbiornik byłby w stanie zretencjonować objętość dużej fali wezbraniowej, wywołanej kilkugodzinnym, wysokim opadem o sumie całkowitej $50 \mathrm{~mm}$.

Uruchomienie zbiornika Pietraszki spowoduje, że w obrębie jego misy naturalne procesy fluwialne i stokowe zostaną zastąpione przez nowe procesy geomorfologiczne związane z funkcjonowaniem akwenu wodnego. Przebieg przyszłych procesów brzegowych w strefie litoralnej zbiornika będzie zróżnicowany przestrzennie i zależeć będzie głównie od morfologii i ekspozycji brzegu, nachylenia stoków (nadwodnego i podwodnego), a także od dynamiki stanów wody, falowania i zjawisk lodowych. Przewiduje się, że procesy abrazji największe rozmiary osiągną na nieumocnionych odcinkach południowo-wschodniej i północno-zachodniej części linii brzegowej. Nastąpi tu podcinanie najbardziej nachylonych fragmentów stoku, gdzie spadki przekraczają lokalnie $4^{\circ}$ (ryc. 6). W obrębie wąskiej strefy brzegowej wytworzy się półka abrazyjna. Procesy te będą trwały wiele lat, aż do osiągnięcia profilu równowagi. W strefie zasilania zbiornika wodami Sufragańca odbywać się będzie akumulacja transportowanego materiału klastycznego. Średni roczny ładunek zawiesiny Sufragańca w przekroju zapory, udokumentowany w latach 1998-2001 (Ciupa 2009), wyniósł 557 t, a ładunek denny - 90 t. Ładunek zawiesiny będzie akumulowany częściowo (ok. 50\%), a ładunek denny w całości, głównie w górnej części zbiornika. W efekcie powstaną delta i płycizny. W północno-wschodniej części akwenu (ok. $50 \mathrm{~m}$ od brzegu), istnieją dogodne, naturalne warunki do uformowania wyspy o powierzchni ok. 1 ha. Jej utworzenie sprzyjałoby podniesieniu walorów krajobrazowych i ekologicznych całego zbiornika.

\section{Wnioski}

Wykazano dużą przydatność danych z lotniczego skanowania laserowego do wielokierunkowej analizy morfologicznej dna planowanego, wielozadaniowego zbiornika wodnego Pietraszki - położonego na obrzeżach Kielc, w zakresie:

- precyzyjnego wyznaczenia przebiegu linii brzegowej na dwóch poziomach piętrzenia;

- modelowania powierzchni oraz określenia kierunku i wielkości potencjalnych przemieszczeń gruntu podczas prac ziemnych, w celu zniwelowania nierówności, 
a zatem zapewnienia bezpieczeństwa osobom korzystającym z walorów rekreacyjnych zbiornika;

- opracowania szczegółowego planu batymetrycznego oraz wskazanie tych części akwenu, w których jest możliwe uprawianie różnych form turystyki wodnej zależnie od głębokości;

- wyznaczenia, na podstawie analizy batymetrycznej i spadków terenu, wzdłuż całej linii brzegowej zbiornika 5 stref rekreacyjnych o różnym przeznaczeniu;

- wskazania obszarów narażonych na wystąpienie wzmożonych procesów akumulacji i abrazji.

\section{Literatura}

Affek A., 2014, Lotnicæe skanowanie laserowe (ALS) w modelowaniu ræeそ́by terenu - nowe możliwości i pułapki, Problemy Ekologii Krajobrazu, 38, 217-236.

Bernardini F., Sgambati A., Montagnari Kokelj M., Zaccaria C., Micheli R., Fragiacomo A., Tiussi C., Dreossi D., Tuniz C., De Min A., 2013, Airborne LiDAR application to karstic areas: The example of Trieste province (north-eastern Italy) from prehistoric sites to Roman forts, Journal of Archaeological Science, 40 (4), 2152-2160.

Borkowski A., Gołuch P., Mokwa M., Tymków P., 2006, Wykorzystanie lotničego skaningu laserowego do budowy numerycænego modelu terenu doliny rzeki Widawy, [w:] Problemy Hydrotechniki, IX konferencja Problemy Hydrotechniki, Złotniki Lubańskie, 24-26 Maj 2006, 171-178.

Brach M., Chormański J., 2014, Terrestrial Laser Scanning (TLS) as a detection method of the natural river valley microtopography - case study of the Upper Biebr $\approx a$, Annals of Warsaw University of Life Sciences - SGGW, Land Reclamation, 46 (4), 267-278.

Bremer M., Sass O., 2012, Combining airborne and terrestrial laser scanning for quantifying erosion and deposition by a debris flow event, Geomorphology, 138 (1), 49-60.

Ciupa T., 2009, Wptyw sagospodarowania terenu na odphyw i transport fluwialny w matych zlewniach na przykładzie Sufragańca i Silnicy (Kielce), Wydawnictwo Uniwersytetu Jana Kochanowskiego, Kielce.

Ciupa T., Suligowski R., 2015, Hydrological conditions of the Pietraszki water reservoir designed for the River Sufraganiec (Kielce), Limnological Review, 4, 145-154.

Ciupa T., Suligowski R., Wałek G., 2015, Geografic»ne uwarunkowania lokalizacji projektowanego zbiornika wodnego na terenie Kielc, [w:] D. Absalon, M. Matysik, M. Ruman (red.), Nowoczesne metody i rozwiqzania w hydrologii i gospodarce wodnej, Monografie Komisji Hydrologicznej PTG, 3, 127-140.

Conrad O., Bechtel B., Bock M., Dietrich H., Fischer E., Gerlitz L., Wehberg J., Wichmann V., Böhner J., 2016, System for Automated Geoscientific Analyses (SAGA) v. 2.1.4, Geoscientific Model Development, 8, 1991-2007.

Dudzińska-Nowak J., Wężyk P., 2006, Moふ̇liwości wykorzystania technologii LiDAR w badaniach strefy bræegowej, [w:] K. Furmańczyk (red.), Bræeg morski - zrównoważony, Uniwersytet Szczeciński, Szczecin, 47-59. 
Filonowicz P., 1973, Szczegótowa Mapa Geologiczna Polski 1:50 000, ark. Kielce, PIG, Warszawa.

Florek W., Tylman I., 2013, Skaning laserowy w badaniach morfologicznych matych dolin ræecznych (przypadek doliny Jarostawianki), [w:] J. Jonczak, W. Florek (red.), Srodowisko glebotwórcze i gleby dolin rzecznych, Wydawnictwo Bogucki, Poznań-Słupsk, 19-32.

Gołuch P., Borkowski A., Jóźków G., Tymków P., 2009, Application of digital terrain model generated from airborne laser scanning data in hydrodynamic modelling, Studia Geotechnica et Mechanica, $31(3), 61-72$.

Höfle B., Rutzinger M., 2011, Topographic airborne LiDAR in geomorphology: A technological perspective, Zeitschrift für Geomorphologie, 55 (2), 1-29.

Jędrychowski I., 2007, Lotnicze skanowanie laserowe w Polsce, Polski Przegląd Kartograficzny, 39 (2), 159-163.

Kasprzak M., Traczyk A., 2010, Geomorfometria granitowej części Karkonoszy, Landform Analysis, $13,33-46$.

Kasprzak M., Traczyk A., 2011, Rzeźba i rozwój doliny Izery w Sudetach Zachodnich, Opera Corcontica, 48, 7-34.

Kowalski M., 2013, Zastosowanie technologii lotnicæego skaningu laserowego na przyktadzie projektu Informatyczny System Ostony Kraju (ISOK) przed nadzwyczajnymi zagrożeniami, Przegląd Geodezyjny, 85 (11), 9-12.

Kowalski M., 2013, Zastosowanie technologii lotniczego skaningu laserowego na przyktadzie projektu Informatyczny System Ostony Kraju przed nadzwyczajnymi zagrożeniami (ISOK), Przegląd Geodezyjny, 85 (11), 9-12.

Kurczyński Z., Bakuła K., 2013, Generowanie referencyjnego numerycznego modelu terenu o zasiegu krajowym w oparciu o lotnicze skanowanie laserowe w projekcie ISOK, Archiwum Fotogrametrii, Kartografii i Teledetekcji, vol. spec., 59-68.

MGGP Aero, 2011, Operat techniczny. Wykonanie skanowania LIDAR \&djęć lotniczych oraz opracowanie na podstawie pozyskanych danych NMT i NMPT, Tarnów.

Migoń P., Kasprzak M., Traczyk A., 2013, How high-resolution DEM based on airborne LiDAR helped to reinterpret landforms - examples from the Sudetes, SW Poland, Landform Analysis, 22, 89-101.

Pawłuszek K., Ziaja M., Borkowski A., 2014, Ocena doktadności wysokościowej danych lotniczego skaningu laserowego systemu ISOK na obszarze doliny rzeki Widawy, Acta Sci. Pol., Geodesia et Descriptio Terrarum, 13 (3-4), 27-38.

Prażak J., 2012, Pozycja hydrodynamicæna $i$ snaczenie gospodarcze dewońskich «biorników wód podziemnych w Górach Świętokrzyskich, Prace PIG, 198.

Sailer R., Rutzinger M., Rieg L., Wichmann V., 2014, Digital elevation models derived from airborne laser scanning point clouds: Appropriate spatial resolutions for multi-temporal characterization and quantification of geomorphological processes, Earth Surface Processes and Landforms, 39 (2), 272-284.

Suligowski R., Kupczyk E., Kasprzyk A., Koślacz R., 2009, Woda w środowisku przyrodniczym województwa świętokrzyskiego, Instytut Geografii UJK, Kielce. 
Tomlin C.D., 1990, Geographic Information Systems and Cartographic Modeling, Englewood Cliffs, NJ, Prentice-Hall.

Webster T.L., Murphy J.B., Gosse J.C., Spooner I., 2006, The application of LIDAR-derived digital elevation model analysis to geological mapping: An example from the Fundy Basin, Nova Scotia, Canada, Canadian Journal of Remote Sensing, 32, 173-193.

Wierzbicki G., Ostrowski P., Mazgajski M., Bujakowski F., 2013, Using VHR multispectral remote sensing and LIDAR data to determine the geomorphological effects of overbank flow on a floodplain (the Vistula River, Poland), Geomorphology, 183, 73-81.

WIOŚ, 2015, Wyniki klasyfikacji i oceny stanu wód powier «chniowych w wojewódætwie świętokrzyskim w roku 2014, Kielce.

WIOŚ, 2016, Stan środowiska w wojewódætwie świętokrzyskim. Raport 2015, Biblioteka Monitoringu Środowiska, Kielce.

Wójcik A., Wężyk P., Wojciechowski T., Perski Z., Maczuga S., 2013, Geologiczna i geomorfologiczna interpretacja danych z lotniczego skaningu laserowego (ALS) rejonu Kasprowego Wierchu (Tatry), Przegląd Geologiczny, 61, 234-242.

Zevenbergen, L.W., Thorne, C.R., 1987, Quantitative analysis of land surface topography, Earth Surface Processes and Landforms, 12, 47-56.

\author{
Tadeusz Ciupa \\ Uniwersytet Jana Kochanowskiego w Kielcach \\ Instytut Geografii \\ ul. Śriętokrzyska 15, 25-406 Kielce \\ tadeusz.ciupa@ujk.edu.pl \\ Roman Suligowski \\ Uniwersytet Jana Kochanowskiego w Kielcach \\ Instytut Geografii \\ ul. Świętokrzyska 15, 25-406 Kielce \\ roman.suligowski@ujk.edu.pl \\ Grzegor: Watek \\ Uniwersytet Jana Kochanowskiego w Kielcach \\ Instytut Geografii \\ ul. Swiętokrzyska 15, 25-406 Kielce \\ grzegorz.walek@ujk.edu.pl
}

